\title{
THE GOURKOVO CITY BIO-RALLY - BETWEEN TRADITION AND ALTERNATIVE TOURISM
}

\author{
B. Stoykova* \\ Department of Regional Development, Faculty of Economics, Trakia University, Stara Zagora, \\ Bulgaria
}

\begin{abstract}
Event tourism, as an alternative form of tourism, has established itself on the Bulgarian market, because it satisfies specific travel demands.

Every year at the beginning of September in the city of Gourkovo, it is held a Bio-rally (donkey cart race), which traditionally attracts many guests and visitors from the country and abroad.

The race with donkey carts is a special local event and it has long since become a trademark of the city. The purpose of this study is to trace and study the development of specialized kind of event tourism in the town of Gourkovo, following the example of the Bio-rally with donkey carts.

Based on a recently conducted survey, an attempt was made to identify tourist's motivational factors for traveling, as well as their satisfaction with the event.

The used scientific methods are analysis and synthesis, induction and deduction.
\end{abstract}

Key words: bio-rally, alternative tourism, event tourism

\section{THEORETICAL BACKGROUND}

The term "event tourism" has become quite popular in contemporary literature as a relatively new type of tourism, which has aroused considerable interest. Here, the primary goal of the journey is to attend a specific event. Event tourism offers a unique festive atmosphere, great conditions for recreation, and unforgettable experiences. The main distinctive feature of event tourism is the multitude of exciting and unique moments. This is a fast-developing type of tourism with great potential (1).

In the beginning of the XXI century, a number of leading authors have claimed that festivals and events comprising a one-time performance within an urban environment or a city performance can bring high economic gains by improving the reputation of the populated areas, their products and institutions. They attract tourist flows, capital and investments. For many cities, the key motivation for the development of strategy and organizing an event, which attracts tourists' interest, is to

* Correspondence to: Blaga Stoykova, Department of Regional Development, Faculty of Economics, Trakia University, Stara Zagora 6000, Bulgaria, email: blaga_st@abv.bg recover from long-term economic stagnation. It can be said that festivals and events are a wider spectrum of new "cultural strategies" $(2,3)$.

A number of researchers view these events as an important engine of tourism, as well as an efficient stimulant for improving the destination's public image $(2,4-9)$.

Special local events attract a varied tourist flow. Studying the motives for their visit is a leading element of the studies. Such studies are very important, in order to find the precise market niche and, to a great extent, to take measures in order to satisfy the visitors' demands.

During the last decades of the XX century several classic studies have been published in English-language literature, with regard to festival motivation related to festivals from various parts of the world, covering a wide spectrum - starting from the USA, passing through a number of European countries and reaching countries in the Middle East and Asia. The key understanding was that marketing could be efficient after examining the motivation for travel (10).

The first studies revealed factors such as: escape from reality; something new and 
unknown; excitement and experiences/thrills; socialization; bring the family closer together (11). The also analyzed the variants of the described factors and activities in terms of demographic variables (12). The differences in the motivations of first-time and recurrent visitors were examined as well (13). The intercultural equivalence of the motivation scale was studied too (14). Factors attracting visitors were distinguished from the factors that repel them (15).

Since the beginning of the XXI century, learning and the external socialization of the group are also taken into account (16). Researchers are also trying to establish the differences among local and foreign visitors (17).

It has been proven that such studies can be helpful for finding new markets and attracting customers.

The current study attempts to answer the question of to what extent a specific local event, which is unique within the country, affects tourism at the populated area. The motivation factors for travel are analyzed, as well as the economic and social benefits from the organization of the so-called bio- rally (donkey cart race) in the town of Gurkovo.

The annual donkey cart race is a special local event that has long become town's trademark. The citizens of Gurkovo recognize the biorally as a distinguishing feature of the small town. They believe that the value of this brand will rise as the years pass and thus work on a marketing strategy for its proper management. The local community believes that the Biorally has become popular as a specific local event. The municipality is even working on a project for the construction of a tourist information center with a museum of donkeys, which will further create good conditions for the development of tourism.

\section{HISTORICAL DEVELOPMENT OF THE CITY OF GURKOVO. CONDITIONS AND BASIS FOR THE DEVELOPMENT OF EVENT TOURISM}

The city of Gurkovo is located within Central Bulgaria, within the eastern end of the Valley of Roses, between the Stara Planina and Sredna Gora mountains.

The settlement's old name was Kolupchii and it originates from the Turkish word "kolagchiyan," which was probably used to designate an outpost or guard settlement. The village was first mentioned under this name within a Turkish registry in 1450 (10).
The village was situated within the foothills of Stara Planina, at the beginning of the Lazovski pass, until 1620, after which it was moved 4 $\mathrm{km}$ to the north. Around 1800, the village moved back to its original position.

During the XIX century, the village was known as Hainkyoi or Haineto (18).

During the Russian-Turkish Liberation War (1877 - 1878), General Gurko and his army passed through the Hainboaz pass, and on July 2, 1877 he stayed for the night at Haineto (19). This is probably the reason why in 1906 the village was renamed to Gurkovo. In 1940, after a publication in the State Gazette, it was renamed to General Gurkovo (18).

Nowadays, the specifics of the geographic location, the terrain features and the socialeconomic profile of Gurkovo establish it as an ecological clean area. The natural-geographic and transport-communication features of the town's territory represent a potential for the development and localization of functions and activities with municipal and international importance. The town of Gurkovo has settlement functions typical for most small municipality centers in the country. The higher population in the city of Gurkovo, in addition to the development of its servicing functions, has also stimulated the development of its economic functions. The economic potential of the city of Gurkovo today is lower than its position towards the end of the 1980's.

During the first decades of the XXI century, a number of small enterprises have distinguished themselves within the economy of the city of Gurkovo, in the field of industry, construction and commerce. The agricultural sector shows potential, which has not been fully utilized yet. The city of Gurkovo exhibits a high extent of urban development (19).

The municipality of Gurkovo has been determined by the Ministry of Regional Development and Urban Planning to be an area with the potential for tourism development, which should be expanded and utilized. One of the main priorities in the municipal plan for the development of the municipality of Gurkovo is economic growth and ecological clean production. Among the goals cited in relation to this priority point is also the development of tourism as an alternative form of economic activity, based on the existing resources. In order to accomplish this goal, the primary measures to be taken include: the construction of tourist infrastructure; improving the existing and building new 
technical infrastructure at the places for tourism and recreation (plumbing and drainage, roads, sewage, communications); improving tourist services, and marketing the municipality of Gurkovo as a good vacation spot (20).

Over the course of fulfilling the listed goals, a Tourist Information Center has been built in the town, along with a Museum of Donkeys, after the implementation of a project funded via the Rural Region Development Programme (2007 - 2013) amounting to a total value of BGN 184431. An exposition of donkey-related accessories has been displayed at the museum. Among them are several items from the $19^{\text {th }}$ century. A photo exhibit including more than 400 photographs tells the story of the Biorally from its first to latest instance. There are also some donkey carts that had participated in the race but are no longer fit for usage (21).

The Gurkovo city Bio-rally has long established itself as a special local event. It owes its decade-long existence to its uniqueness, which continues to attract spectators even today.

The race's long-standing history has created and solidified a sustainable tradition that the local population is proud of. In practice, this event has turned into a primary tourist attraction. It brings a large and varied audience, which merges into the general tourist flow of the town and municipality. The citizens determine it as a main local cultural event.

The idea originated in 1971 within a rented flat in Sofia, where three students from Gurkovo Stoyan Bogdanov, Ivan Runtev and Iliya Todorov promised their fellow students an unforgettable experience in their native town. Thus they organized the first bio- rally in Gurkovo on September 10.

Nowadays, participation in the bio- rally requires the preparation of a donkey cart, which has to be well-decorated, in order to be attractive. It should be noted that some participants transform their carts into spaceships, helicopters, ambulances, combines or pirate ships.

To qualify for participation in the race, the donkeys undergo training as well. To this end, for several days before the race, the donkeys are fed with stronger food - special feed or alfalfa, but not "ordinary straw."

Doping is strictly forbidden during the races. The usage of hot peppers and horsefly is not allowed. All donkeys undergo a medical examination before the start - condition of the teeth, cardiac activity, hooves.

The competition passes through five disciplines - best decorated cart, quick harnessing and unharnessing, racing, "naked" riding, and pulling of donkey carts for strength and endurance. In this case "naked" riding does not mean riding without clothes, but rather without a saddle. Donkey football is the most attractive competition with optional participation. The prizes are specific as well. The winner always receives bio-fuel (wheat or alfalfa) and a cubic meter of lumber for the construction of a new cart. The other contestants receive material awards or monetary premiums.

The organizers of the bio-rally have accepted a primary rule that this competition should have the minimum possible effect on the animals, via a cautious approach. This is important not only for the welfare of the animals, but also for the local community, which perceives the "biorally" as a local trademark. Furthermore, the event's impact on the local economy should also be taken into account, with regard to the development of tourism. The event has to be managed in a way that preserves ecological values, without exploiting the animals and using violence on them.

\section{OBSERVATIONS AND ANALYSIS ON THE GURKOVO CITY BIO-RALLY}

The data for the separate components of the present study were received from the primary sources and are based on a survey conducted via a questionnaire addressed to the guests and participants at "GOURKOVO CITY BIORALLY - 2012" that took place on September 1, 2012. Direct interviews were conducted on the day the event was held. The formed sample was the result of stratification based on the participants and guests at the Gourkovo city Bio-rally, selected at random, which led to the completion of 71 successful interviews. While calculating the final results, the surveys underwent additional processing in order to filter out all inadequate or illogical responses.

While preparing the questionnaire to gather empirical information for the present study, questionnaires from previously conducted and published studies on similar topics were used as a model (22-25).

The questionnaire for the survey consisted of four parts:

- The first part examined the demographic profile of the participants, as well as the respondents' social and public status. 
- The second part included questions encompassing the behavioral character of the event participants.

- The third part asked the respondents to point out the motivating factors for their journey.

- The fourth part was related to the structuring of the economic and intangible benefits to the local community.

Analysis of data from questionnaires. Results:

From all participants in the survey, $49 \%$ were men and $46 \%$ - women. Four per cent of respondents did not declare any specific gender.

The distribution of respondents according to their marital status was as followed: $32 \%$ single; $46 \%$ - married; $13 \%$ - cohabitation without marriage, $8 \%$ did not respond to this question.

According to their age, $10 \%$ of the respondents were $<20$ years of age, $31 \%$ - between 20 and 29 years; $18 \%$ - between 30 and 39 years; $21 \%$ - between 40 and 49 years; $13 \%$ - between 50-59 years and only $4 \%$ - between 60 and 69 years. Age was not specified by $3 \%$ of people.

Most numerous were visitors with secondary educational degree - 54\%, followed by respondents with higher education $-27 \%$, while only $7 \%$ have stopped their education at

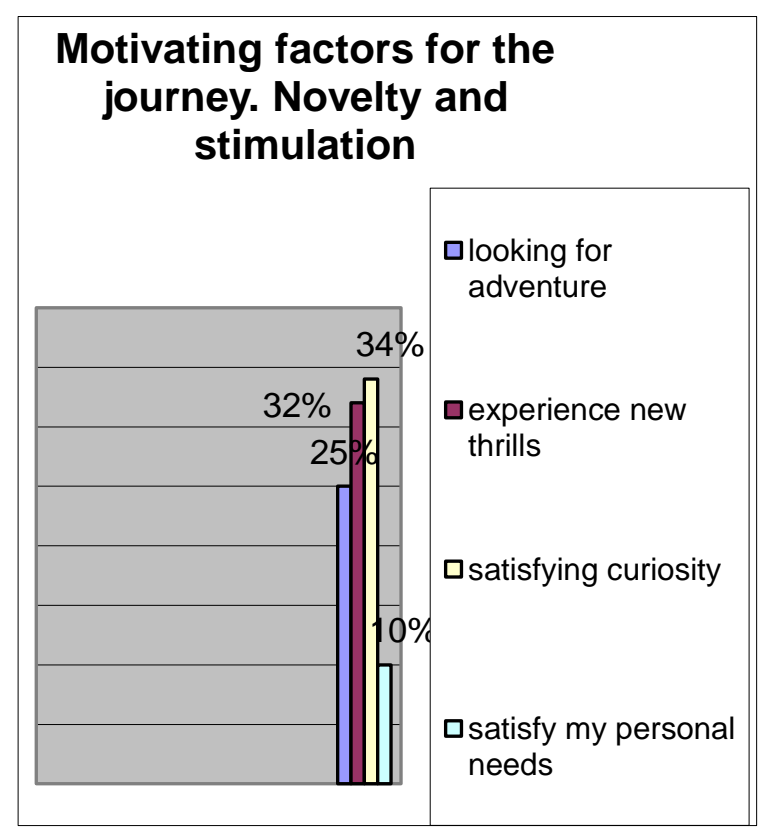

Figure 1. Motivating factors for the journey. Novelty and stimulation

According to the results, the lowest influence had motivation factors such as coping with the elementary school level. Undergraduate students were $7 \%$, high school students $-4 \%$, and elementary school students $-3 \%$.

The data from the survey exhibited a substantial diversity with respect to the social status of visitors. Students, both high school and undergraduate comprised $21 \%$ of all respondents. One fifth (20\%) were unemployed. Private businessmen were $17 \%$, and $11 \%$ - municipal or state employees. The same was the proportion of men with specialization. Retired persons and those engaged in sales and marketing business were $7 \%$ each. Six per cent were craftsmen. Only $4 \%$ were unskilled labourers. Employed people which did not specify a specific profession were $13 \%$.

The visitors of the Bio-rally were also requested to mentioned their monthly income. The results showed a rather broad range as monthly income was concerned from less than 200 BGN to 2000 BGN. The people earning up to 400 BGN per month prevailed with a a very small difference $-25 \%$, followed by those with income up to 600 BGN - $17 \%$ and $15 \%$ with income up to 200 BGN. In descending order$8 \%, 7 \%$ and $6 \%$ - were the shares of spectators having declared incomes of up to 800 , up to 1400 and up to 2000 BGN.

More than half of respondents have previously visited the Bio-rally - $66 \%$, as compared to first-time visitors - only $23 \%$.

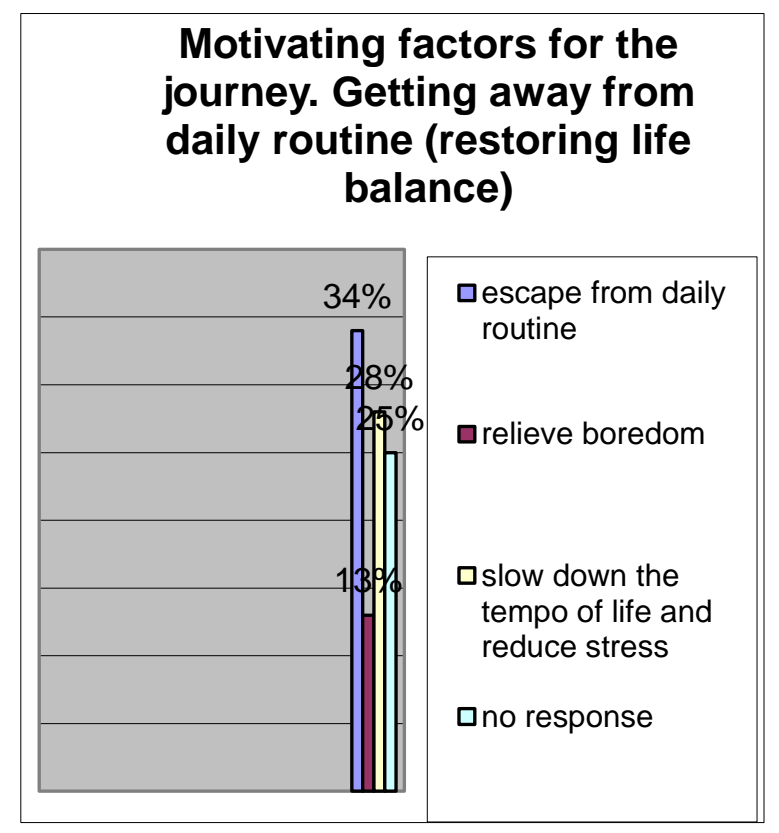

Figure 2. Motivating factors for the journey. Getting away from daily routine (restoring life balance)

boredom and meeting one's personal needs.

Most of respondents have declared as 
motivation factors for the journey satisfaction of curiosity, escape from everyday routine, experiencing new emotions, slowing down the

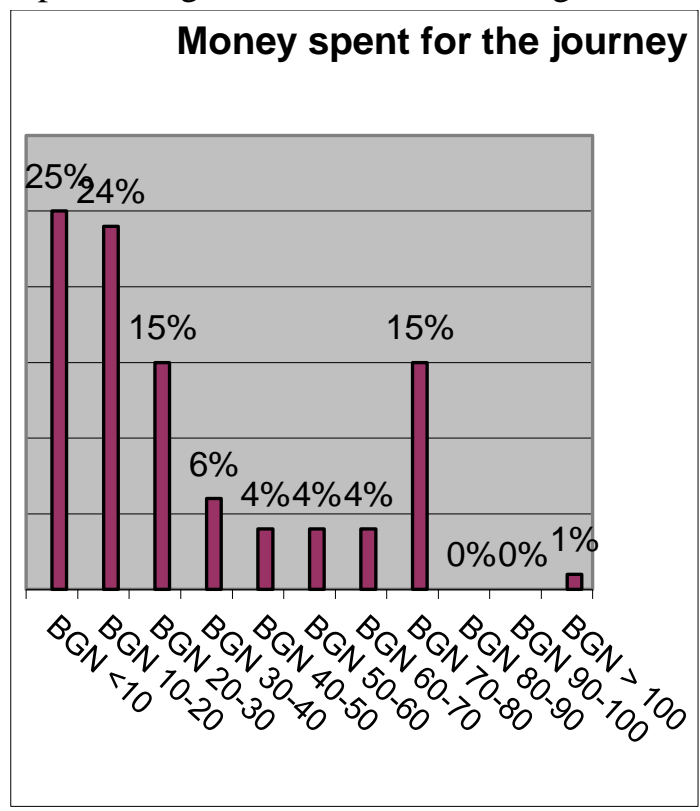

Figure 3. Spent money

The highest share of visitors have spent less than BGN 10 during the journey (25\%), followed by those having spent between BGN 10 and 20 (24\%). Fifteen per cent of spectators have spent between BGN 20 and 30; the same was the proportion of people who spent between BGN 70 and 80 . Only $1 \%$ of respondents spent more than BGN 100 (Figure 3). An interesting relationship was found between the small amount of money spent during the event by most visitors having everyday rhythm of life, reduction of stress

(Figure 1 and Figure 2).

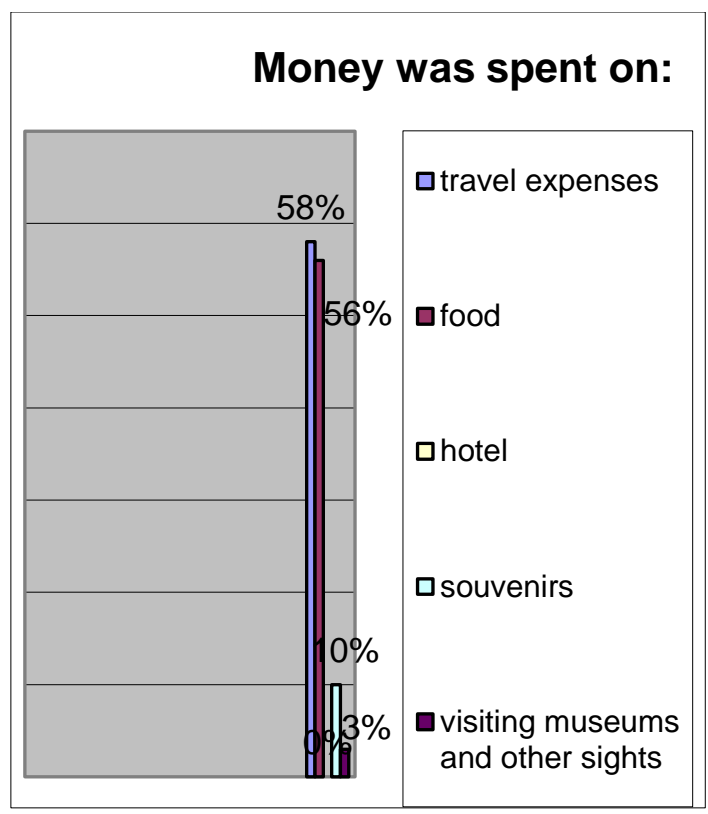

Figure 4. Types of expenses

declared income about or under the average for the country.

The distribution of the amount of money spent comprised: travel expenses (58\%), food expenses $(56 \%)$ and purchase of souvenirs $(10 \%)$. Of all visitors, $3 \%$ have spent some money for museums and other show places. None of respondents had accommodation expenses (Figure 4).

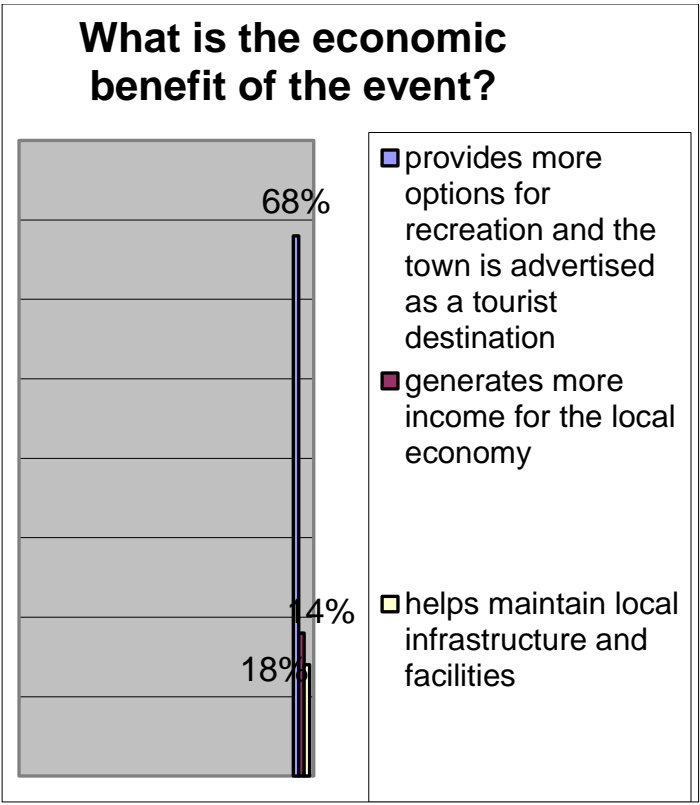

Figure 5. Economic benefit

When asked about the economic benefit from the event, $68 \%$ expressed the opinion that the

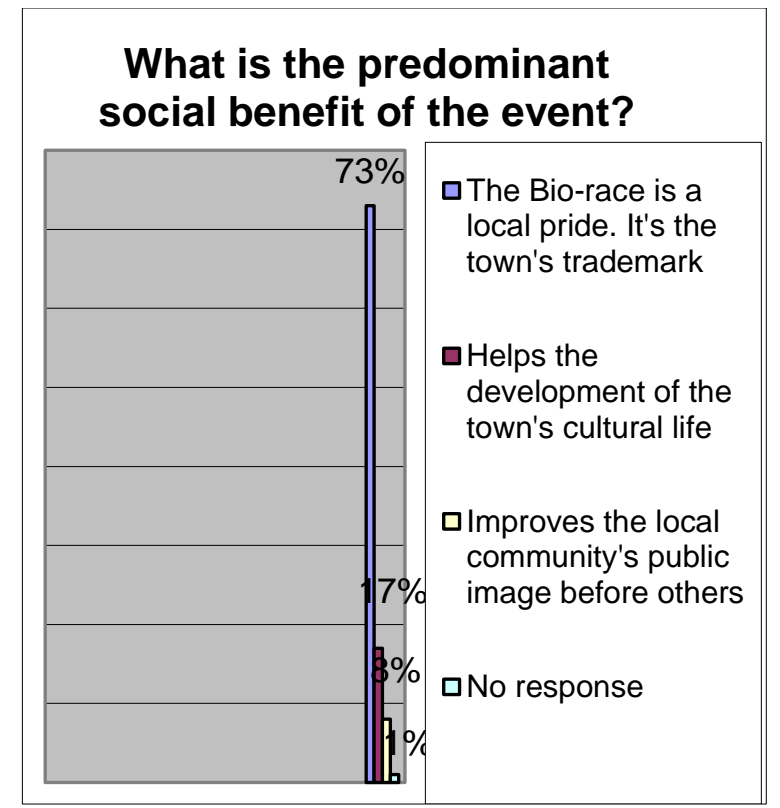

Figure 6. Social benefit

event offers more options for recreation and advertized the town as a tour destination. 
Eighteen per cent suggested that this generated more income for the local economy. Fourteen per cent believed that the conducting of the Bio-rally supported the maintenance of the local infrastructure and facilities (the event is traditionally held in a stadium) (Figure 5).

Regarding the intangible benefits from the event, the greatest share was made up by people who said that the bio- rally was a local pride, a trademark of the town (73\%). Seventeen per cent accepted the event as a part of the local cultural calendar and believed that it supported the development of the town's cultural life. Eight per cent declared that this event improved the public image of the local community (Figure 6).

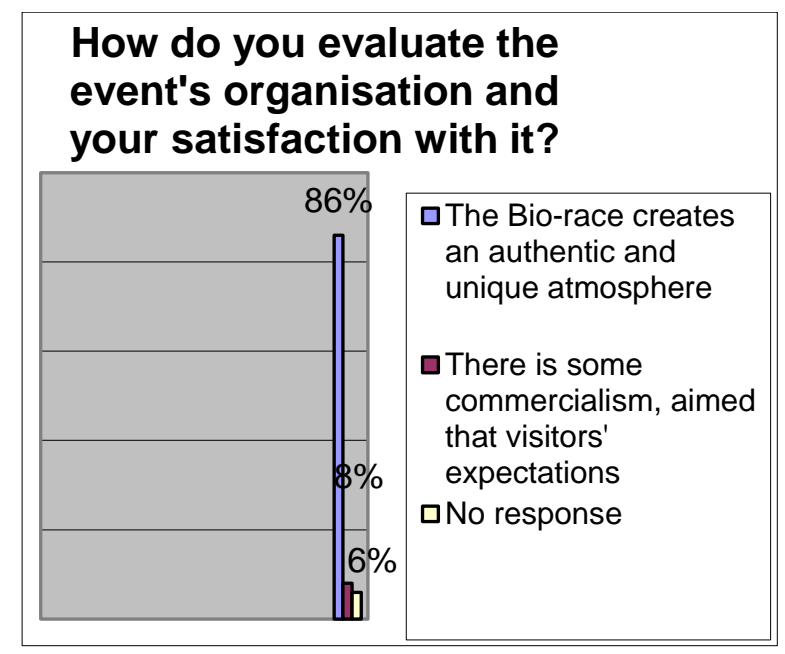

Figure 7. Satisfaction of the event

Examining the visitors' satisfaction produced results, which indicated that $86 \%$ of the attendees have declared that the Bio-rally created an authentic and unique atmosphere. The observed high values of the empirical data, which confirmed its authenticity, led to the conclusion that the organizers are wellacquainted with the specifics of this local event and aim to preserve its unique character. At the same time, it should be noted that, regardless of the low percentage (merely $8 \%$ ), some of the interviewed attendees have felt commercialization aimed at meeting the visitors' expectations (Figure 7).

Special local events gain an identity of their own not only via their wide far-reaching presentation, with the special role of the cultural-historical context - the town's tradition. At the same time, with their popularization, the town receives a specific kind of legitimacy on the global tourist map. The mutual dependence between tourism and organizing special local events for the purpose of attracting visitors, is an important factor for the success of a tourist destination. The Bio- rally in the town of Gurkovo combines the development of alternative forms of tourism and the preservation of the local tradition, which is, to an extent, a guarantee for success.

\section{CONCLUSIONS AND RECOMMENDATIONS}

The uniqueness and natural specificity of the Gourkovo city Bio-rally is a good precondition for the development of alternative forms of tourism in the town. The local populace plays a significant role in this process, by demonstrating their pride with the trademark and declaring their decisiveness to preserve it for posterity.

At the same time, this special local event should be viewed as a source of and precondition for economic and social development because an increasing number of tourists wish to experience new thrills, and escape from the boredom of daily routine.

The specifics of the Bio-rally is related to the participation of animals and the competition among them for the entertainment of the attendees. And here we cannot avoid the issue of the extent, to which human recreational activities affect animals and the potential ill consequences for their health, physiological and behavioral reactions. The event organizers face the challenging task of reducing the animals' physiological stress to a minimum by taking action to mitigate it, as well as implement strict rules for the participants in the different contests.

Something we observed over the course of the study was that access was still difficult and there was no adequate infrastructure for the event attendees - such as proper parking spots. The attendance of the Bio-rally was directly dependant on previous participations, as well as on the recommendations of friends and relatives, which affect the formation of preferences.

For the future, we could recommend that the organizers advertise the event more intensively, along with active participation at tour expos, in order to popularize it further.

As a whole, there is no clear strategy and policy for the management and unification of the various forms of alternative tourism within the territory of Gurkovo. The visitors usually came for a one-day stay and did not fully utilize all tourist attractions that the town and the surrounding populated areas can offer. Therefore, some thought can be put into producing a well-balanced and cohesive tourist package, which the city of Gurkovo can offer to its visitors. The organizers of the Bio-rally 
could think about establishing a connection with tour operators, in order to attract more visitors to the event. The tourist package could also be enriched with visits to other sights in the area and the surrounding villages. This will increase the economic benefits for the municipality.

The positioning and perception of the brand "Gourkovo city Bio-rally" are related to the promise that the consumer will enjoy an authentic and unique atmosphere during their visit. The lack of competition due to the uniqueness of the event requires good knowledge of the tourist market in Bulgaria by the organizers, in order to build up a clear long-term strategy for the development and establishment of a trademark, which would embody the feel of a one-of-a-kind specific local event.

\section{REFERENCES}

1. Babkin A.V., Special kinds of tourism, Rostov na Don, 2008, see also http://spbkspo.com/13052010/turism/babkin.doc

2. Quinn, B Festivals, events and tourism, in Jamal, T. and Robinson, M. (Eds) The SAGE Handbook of Tourism Studies. London: $\quad$ Sage, 2009; http://arrow.dit.ie/cgi/viewcontent.cgi?articl $\mathrm{e}=1000 \&$ context $=\mathrm{tf}$ schhmtbook

3. Schuster, J. Mark'Ephemera, Temporary Urbanism, and Imaging, In: Lawrence J. Vale and Sam Bass Warner Jr. (eds.), Imaging the City-Continuing Struggles and New Directions (New Brunswick, New Jersey: CUPR Books), 2001.

4. Jonas, Andrew E.G., Wilson, D., The Urban Growth Machine. Perspectives Two Decades Later., State University of New York Press, Albany, p.55, 1999; http://books.google.com/books?id=kWN5dhflJ8C\&printsec=frontcover\&hl=bg $\&$ source $=$ gbs_ge_summary_r $\&$ cad $=0 \# v=$ on epage $\& q \& \mathrm{f}=$ false

5. Getz D. Event Tourism: Definition, Evolution, and Research. Tourism Management, 29:403-428, 2008; http://www.sciencedirect.com/science/articl elpii/S0261517707001719

6. McCann, Eugene J., The cultuaral politics of local economic development: meaningmaking, place-making, and the urban policy process. Geoforum 33, pp. 385-398, 2002 ; http://www.sciencedirect.com/science/articl e/pii/S0016718502000076

7. Ritchie, JRB., Assessing the impacts of hallmark events: conceptual and research issues, Journal of Travel Research , 23(1): 2-11, 1984; http://jtr.sagepub.com/content/23/1/2.short
8. Choong-Ki, Lee, Yong-Ki, Lee, Bruce E. Wicks, Segmentation of festival motivation by nationality and satisfaction, Tourism Management ， 25: 61-70, 2004; http://www.sciencedirect.com/science?_ob $=$ MImg\&_imagekey=B6V9R-48R7C0Y-1$1 T \&$ cdi $=5905 \&$ _user $=2738094 \&$ _orig $=$ se arch\&_coverDate $=02 \% 2 \mathrm{~F} 29 \% 2 \mathrm{~F} 2004 \&$ \&sk $=999749998 \&$ view $=c \& w c h p=$ dGLbVtz zSkWb\&md5=2e206de8da506cbd33062fe5 3f134162\&ie $=/$ sdarticle.pdf

9. Vásquez J.-L., R. Alvarez, I. Georgiev, Al. Naghiu, Role of Bulgarian country image as international rural tourism destination: A real choice?, Trakia Journal of Sciences, Vol. 3, №7, pp.37-41, 2005.

10.Fodness, D., Measuring tourism motivation. Annals of Tourism Research, 21(3): 555-581, 1994.

11.Uysual, M., Gahan, L. \& Martin, B., An examination of event motivations: A case study. Festival Management and Event Tourism, 1: 5-10, 1993.

12.Backman, K.F., Backman, S.J.U., Uysal, M. \& Sunshine, K.M., Event tourism and examination of motivations and activities. Festival Management and Events Tourism, 3: 15-24, 1995.

13.Scott, D., A comparison of visitors' motivations to attend three urban festivals. Festival Management and Event Tourism, 3: 121-128, 1995.

14.Schneider, I.E. \& Backman, S.J., Crosscultural equivalence of festival motivations: A study in Jordan. Festival Management and Event Tourism, 4: 139-144, 1996.

15.Crompton, J.L. \& McKay, S.L., Motives of visitors attending festival events. Annals of Tourism Research, 24 (2): 425-439, 1997.

16.Lee, C., A comparative study of Caucasian and Asian visitors to a cultural Expo in an Asian setting. Tourism Management, 25 (1): 61-70, 2000.

17.Lee, Ch.-K., Lee, Y.-K., Wicks, B.E. , Segmentation of festival motivation by nationality and satisfaction, Tourism Management, 25: 61-70, 2004.

18.Petkov, M., Gurkovo, Sofia, 1989.

19.Borovski, I, Past, present and recommendations for the future development of General Gurkovo village, Kazanlak district, Kazanlak, 1944.

20.Municipal plan for development of the Gurkovo municipality 2007-2013.

21.Project "Tourist Information Centre with Donkey Museum in the town of Gurkovo", Contract № 24/313/00066 of 16.07.2012 European Agricultural Rural Development Fund: Europe invests in rural regions. Rural Development Programme 2007-2013, 
measure 313 „Encouragement of tourism activities".

22.Esu, B.B., Branding Cultural Festival as a Destination Attraction: A case Study of Calabar Carnival Festival, International Business Research, Vol. 2, № 3, July 2009, pp.182-192.

23.Richards, G., Cultural Attractions and European Tourism, CAB International, Wallingford, pp. 35-51, 2001.
24.Picard, D., M. Robinson, Festivals, Tourism and Social Change, Clevedon: Channel View Publications, 2006.

25.Chang, J., Segmenting tourists to aboriginal cultural festivals: An example in the Rukai tribal area, Taiwan, Tourism Management, 27: 1224-1234, 2006. 